\title{
Performatívnost' stredovekého rituálu Mandatum u Sv. Jiří na Pražskom hrade
}

\author{
Performativity of the Medieval Ritual of Mandatum \\ From the Basilica of St. George in the Prague Castle
}

Anna Žáková

\begin{abstract}
Abstrakt
V bohatom spevnom repertoári Zeleného štvrtku v svatojiřskej liturgickej tradícii mal zvláštne postavenie súbor skladieb spojený s rituálom umývania nôh, išlo o tzv. Mandatum. V ôsmich procesionáloch identický repertoárový korpus, ktorého obsah sa odvíja od evanjeliového príbehu (Ján 13,1-17), je obohatený o silný ženský aspekt vychádzajúci z inej evanjeliovej scény (Lukáš 7, 36-50). Toto prepojenie zapríčiňuje kompozičné presahy repertoárov viacerých sviatkov. Forma praktickej realizácie tohto rituálu tak, ako ho nachádzame v liturgických smerniciach kláštora v tzv. ordo, vel'mi konzekventne narába s textom tak v literárnej ako aj symbolickej rovine, takisto dôsledne používa nielen liturgické nástroje, ale tiež akoby "rekvizity". Z tohto pozorovania vychádzajú otázky o dramaturgickej ciel'avedomosti tejto slávnosti ako aj o jej performatívnom potenciáli.
\end{abstract}

\section{Klíčová slova}

liturgia; Zelený štvrtok; umývanie nôh; pedilavium; Mandatum; ordo; rituál; procesionál; Mária Magdaléna

\begin{abstract}
The rich choral repertoire for the Maundy Thursday in the liturgical tradition of the St. George included, among other numbers, a collection of compositions related to the ritual washing of feet called Mandatum. The corpus, identical in eight different processionals, the narrative of which is based on the story related in John's Gospel (John 13,1-17), is enriched by a prominent female aspect drawn from another New Testament scene (Luke 7, 36-50). This connection results in compositional analogies between different liturgical feasts drawing from the given scenes. The extant form of the ritual, found in the liturgical ordo of the monastery, shows concise treatment of the liturgical text both in literary and symbolic way, employing consistently liturgical vessels as well as other "props". These observations bring up questions about dramaturgy of potential performances of the ritual and its theatrical aspects.
\end{abstract}

\section{Keywords}

liturgy; Maundy Thursday; washing feet; pedilavium; Mandatum; ordo; ritual; processional; Mary Magdalene 
Pod pojmom stredoveké divadlo môžeme vnímat̉ mimoriadne pestrú škálu divadelných foriem a prejavov. Ich striktné rozdelovanie na sekulárnu a cirkevnú formu vnáša do oboch oblastí špecifická, ktoré sa takmer v žiadnej rovine nepretínajú, a to dokonca ani v rámci diváckej platformy, hoci sa v divadelnej historiografii o tom mnoho polemizovalo. Ambíciou tohto textu nie je špekulovat nad touto dualitou, pokúsim sa skôr poukázat’ na dôslednost’ dramaturgického myslenia na konkrétnom prípade rituálu umývania nôh, ktorý by sme mohli zaradit do úzkej oblasti liturgickej drámy. ${ }^{1}$

\section{Liturgický základ pre rituál}

Liturgia je podstatou dôležitej, komplexnej a predsa nie celkom presne definovanej oblasti, s ktorou sa v súčasnej terminológii spája slovo „rituál“ (HAVSTEEN, PETERSEN a SCHWAB 2007). Hoci tento termín nevystihuje presne fundament konania samotného, blíži sa k dobovému termínu „ordo“, ked’že samotné slovo „liturgia“, v stredoveku neznámy výraz, je taktiež súčastou novej terminológie. Ordo možno chápat ako súbor predpisov a zvyklostí usmerňujúcich realizáciu bohoslužobných úkonov, od tých najbežnejších až po tie, ktoré svojím vybočením z ordinárnosti iniciovali senzuálne vnímanie obradu ako čohosi výnimočného, ako ojedinelej slávnosti. Éric Palazzo hovorí, že „prvotnou funkciou liturgie je aktivovat zmysly počas uskutočňovania rituálu, aby sa tak liturgickým slávením vyvolal požadovaný teologický efekt." (PALAZZO 2016: 12)

Je dôležité povedat', že kláštorné spoločenstvá spolu s kanovníckymi zbormi (kňazské komunity pôsobiace bud' pri diecéznych katedrálach pod správou biskupa alebo v kolegiátnych chrámoch, ktoré nemali biskupský stolec) formovali každodenným uskutočňovaním súboru modlitieb konštrukciu bohoslužieb, a to s absolútnou pravidelnostou. Ich pôsobenie je skeletom ${ }^{2}$, či skôr východiskom pre schopnost’ vnímat akékolvek vybočenie z ordinárnosti. A teda v dôsledku automatickej pravidelnosti účasti kléru na bohoslužbách sa vytvoril priestor pre úvahy, akým spôsobom zvýraznit’ slávnost', na prvý pohlad ju odlíšit od každodennosti a efektívne zapôsobit na zmysly schopné vnímat ju tak, pretože kostra ostáva v zásade rovnaká. ${ }^{3}$ Rodia sa tak idey, ktoré v sebe nesú dramatický potenciál a schopnost’ prerást̉ do nových „dramatických“ prejavov. Napriek presnosti zámeru a mnohovýznamovosti pridaných elementov z náboženského hladiska, z pohladu dramatickosti ide o konanie náhodné, či skôr také, ktoré nevníma performativitu v zmysle teatrality, ale viac ako náboženský akt. Liturgia ostáva liturgiou, avšak princíp

1 Výraz liturgická dráma používam v tomto zmysle ako univerzálny pojem, ktorý bol bližšie špecifikovaný a definovaný na viacerých úrovniach (Osterfeiern, Osterspiele) Cf. (LIPPHARDT 1975; BERGER 1976; LEWAŃSKI 1966 a PETERSEN 2004).

2 Týmto skeletom nazývam každodennú modlitbu ofícia, vychádzajúcu z Pravidiel sv. Benedikta (6. st.), sformovanú spievaním žalmov, antifón, hymnov a čítaní sedemkrát denne a raz v noci. Vel’konočné slávnosti sa viažu predovšetkým k poslednej časti nočnej a zároveň najkomplexnejšej modlitby - matutínu. Kanovnícke zbory mali rovnakú povinnost', avšak počet jednotlivých žalmov a spevov bol o niečo užší.

3 Žalmy klérus spieval, resp. deklamoval spamäti, pretože ich repertoár sa každý týždeň opakoval. Toto zautomatizovanie je takisto dôležitým východiskom pre extra-ordinárne liturgické prejavy. 
performancie so zapojením pokial možno všetkých zmyslov s cielom pôsobit na vnem človeka, účastníka liturgie, je zrejmý.

Príležitosti pre akcentovanie slávnostného charakteru vychádzajú z cyklu liturgického roku, ktorý je s miernym posunom implantovaný na priebeh kalendárneho roku. Jeho usporiadanie odzrkadluje život Krista: začína adventom, teda očakávaním narodenia, vzápätí pokračuje dôležitým medzníkom (Vianoce), po ňom nasleduje zjavenie Krista (Epifánia), pripomenutie začiatku jeho verejného pôsobenia; jeho zápasy s diablom a tiež vykonané zázraky majú byt povzbudením pre ludské zápasy (pôst), po ktorom prichádza triumfálny vrchol, teda zmŕtvychvstanie (Velká Noc), zjavovanie Krista, jeho nanebovstúpenie, zoslanie Ducha (Letnice) a napokon posledná čast', tzv. ordinárne obdobie, kedy sa cirkev v nadväznosti na prijatie Ducha transformovala z božskej do ludskej podoby pôsobením Kristových učeníkov, a počas ktorého si pripomína jeho učenie až do opätovného začiatku tohto cyklu. Jednotlivé časti liturgického cyklu sa opierajú o biblické príbehy, každá teda disponuje fabulou, na ktorú sa d’alej viažu ostatné rituálne prejavy a spôsobujú tak vnem.

\section{Obrad umývania nôh}

Rituál, ktorý patrí k obohateniu liturgie Zeleného štvrtka a teda treba naň nahliadat vo svetle celkového velkonočného slávenia, sa nazýva Mandatum. ${ }^{4}$ Jeho námetom je scéna z Evanjelia podla Jána (13, 1-17), ked' Kristus pri poslednej večeri umyl nohy svojim učeníkom a toto gesto nazval „prikázaním“ vzájomnej bratskej lásky, ktoré treba nasledovat. Gesto umývania nôh má pre cirkevné komunity obzvlášt významnú úlohu. Jeho inštalácia v západnej liturgii však bola pozvolná. Postupne sa z krstnej liturgie transformoval na nezávislý rituál Mandatum, ktorý sa stal súčastou liturgie Zeleného štvrtka. ${ }^{6}$ Je dôležité pripomenút, že akt umývania nôh znamenal podla reguly v benediktínskej tradícii gesto pokory, prijatia (napr. pútnikov) a vzájomnej lásky a mal viacero podôb.7 Iným potvrdzujúcim prameňom benediktínskej proveniencie tohto rituálu je

4 Názov pochádza z latinčiny, a to z hieronymovského prekladu Kristovho výroku, ktorý je klúčový v napodobovanej scéne: „Mandatum novum do vobis, ut diligatis invicem, sicut dilexi vos.“ (Nové prikázanie vám dávam, aby ste sa navzájom milovali, ako som ja miloval vás.) (Ján 13, 15).

5 Zmienky o rituáli, ktorý bol súčastou krstnej liturgie, nachádzame už v 4. stor. v Ambrózovom De Sacramentis, takisto aj v Augustínovom liste Januáriovi (6. st.), neskôr v Missale Gothicum (koniec 7. st.) a tiež v benediktínskom Bobbio Missali (predkarolínska doba).

6 Hovorí o ňom Toledský koncil (694), tiež dokument Írskeho koncilu Hybernensis (koniec 7. st.), o storočie neskôr je to dokument Aachenského koncilu, modlitbu spojenú s rituálom nachádzame v Gelasiánskom sakramentári (8. st.), prvé podrobné opisy o priebehu obradu a jeho repertoáru sa vyskytujú v 10. st. v dokumente Pontificale Romano-Germanicum. Cf. (LECLERCQ 1929-1931: 1387-1388 a 2007; KANTOROWICZ 1956: 203-251). Amalarius vo svojom spise Opera Liturgica Omnia hovorí o trojakom umývaní - umývaní nôh na Zelený štvrtok, umývaní nôh pocestným pútnikom a umývaní chrámových stien na Zelený štvrtok ( $C f$. AMALARIUS, ed. Hanssens 1948: art. 35-41).

7 Pravidlá sv. Benedikta hovoria o umývaní nôh v kapitole 35 o výmene služby v kuchyni a takisto o tom, že nikto nemôže byt dišpenzovaný od služby bratom; d'alej v kapitole 53 o prijímaní hostí, kde opát najskôr umyje hostovi ruky a potom nohy a v tom ho nasleduje celá komunita. 
Regularis Concordia z 10. storočia, ${ }^{8} \mathrm{v}$ ktorom nachádzame opis obradu umývania nôh a takisto aj zmienku o symbolickej večeri a o niekolkých d’alších zelenoštvrtkových úkonoch opáta a bratov benediktínskej komunity. Dokument umožňuje časovo situovat rituál pred poslednú modlitbu ofícia monastického dňa - pred kompletórium. Takisto to naznačujú aj iné rukopisy z tejto doby, ako antifonáre (knihy spevov) a uzuály (súpisy zvyklostí daného kláštora). ${ }^{9} \mathrm{~V}$ mnohých kláštoroch sa na Zelený štvrtok praktikovalo tzv. dvojité Mandatum - jedno po omši počas dňa, kedy hlavný celebrant či opát vyšiel, aby poumýval nohy dvanástim chudobným (často išlo o deti), spájali sa s tým aj milodary rozdávané chudobným. Preto sa tento obrad nazýval Mandatum Pauperum. Druhé sa nazvalo Mandatum fratrum (Mandatum bratov) alebo sororum (sestier) - podla toho, či išlo o mužský alebo ženský kláštor - a odohrávalo sa večer v kruhu danej komunity, po obrade samotnom nasledovala symbolická večera.

\section{Témy}

Obyčajne sa v textoch spevného repertoáru sprevádzajúceho obrad Mandata prepájali tri rôzne témy. Centrálna téma, spravidla najrozvinutejšia, vychádza z už spomínanej evanjeliovej scény, ked' Ježǐš umyl nohy svojim učeníkom. Jednotlivé spevy citujú tento biblický text. Okrem niekolko málo výnimiek repertoár vel’mi často odkazuje na inú, podobnú biblickú scénu, ktorú nájdeme až v troch evanjeliách. Opisuje situáciu, ked' v Šimonovom dome hriešnica, v stredovekom vnímaní Mária Magdaléna, umyla nohy Kristovi a pomazala ich vzácnymi olejmi. Chronologicky je tento príbeh situovaný len niekolko dní pred poslednou večerou a smrtou Krista. ${ }^{10}$ Zároveň „dispozične ide o dve analogické scény, takmer ich vzájomnú fúziu“ (RENAUD-CHAMSKA 2008: 89). Upozorňuje na to aj liturgia. Zelený štvrtok je integrálnou súčastou Velkého týždňa, ktorý predchádza sviatku Velkej Noci. Od nedele do piatku je každodenne hlavným čítaním pašiový príbeh, pre variáciu každý deň od iného evanjelistu. Výnimkou je štvrtok, kedy sa číta o Kristovom umývaní nôh pri poslednej večeri a pondelok, ktorého hlavné čítanie rozpráva o Máriinom umytí nôh Kristovi. Akoby boli tieto dva texty o "pedilaviu“ umývaní nôh, vo vzájomnom vzt̉ahu. Kristovo gesto o niekolko dní predchádza (tak ako v evanjeliu) laskavý skutok Márie Magdalény. Práve preto aj obrad umývania nôh tieto dva námety prepája. Tretia téma Mandata je istým druhom konklúzie dvoch historických udalostí, a tou je „caritas“, teda krestanská láska. Spevy, ktoré ju reprezentujú, majú viac poetický ako naratívny charakter. Repertoár sa však všeobecne líšil od miesta $\mathrm{k}$ miestu, a takisto aj zastúpenie jednotlivých tém bolo často výsledkom želaného charakteru a dôležitosti tohto rituálu v danom mieste.

8 Rukopis je pre teatrológov známy predovšetkým kvôli opisu velkonočnej slávnosti Quem queritis. Kódex je v skutočnosti komplexným súpisom liturgických smerníc liturgického roku pre benediktínske prostredie editovaných sv. Æthelwoodom a mníchmi z kláštorov vo Fleury a v Gente.

9 Konkrétne napríklad Hartkerov antifonár káštora St. Gallen, súčasník Regularis Concordia, v ktorom je zaznamenaný spevný repertoár pre tento obrad alebo uzuály z kláštorov v Regensburgu, či v Einsiedeln.

10 Ked’ hriešnica umyje Kristovi nohy, ten začne hovorit o svojej smrti, no ostane bez pochopenia. „Ked’ vyliala ten olej na moje telo, urobila to na môj pohreb." (Matúš 26, 12) 


\section{Teatrologické náhl'ady}

Už začiatkom 20. storočia si teoretici kládli otázku, ako z teatrologického hladiska rituál Mandata uchopit', do akej miery ho možno považovat’ za dramaticky potenciálny a prečo ho naopak z rámca liturgickej drámy vyňat. Edmund Kerchever Chambers hovorí o „spomienkovej slávnosti umývania nôh“ a na jej jednotlivé časti nahliada ako na „fragmenty s potenciálom dramatického rozvoja“ (CHAMBERS 1966: 6). Viac sa však k téme ani k jej variáciám nevyjadruje. Karl Young argumentuje na príklade obradu z francúzskeho Besançonu, na ktorom pozoruje možnosti obradu transformovat sa v dramatický tvar. Aby to tak naozaj bolo, kladie podmienku „personifikácie“ hlavného predstavitela do osoby Krista a o tom Youngom študované stredoveké dokumenty nehovoria (YOUNG 1967: 98-100). O. B. Hardison vníma Mandatum ako završujúcu slávnost’ pred vel'konočnou drámou. Táto fáza začína smútkom Smrtnej nedele ${ }^{11}$ a završuje ju ceremoniál umývania nôh, čo sprítomňuje znak krestanskej lásky. „Jeho reprezentatívny element k tomu prispieva a tak oživuje udalosti, ako aj protagonistu vel'konočnej drámy pred očami všetkých účastníkov.“ (HARDISON 1965: 127-128) Blandine-Dominique Berger do diskusie prispieva len akýmsi zhrnutím predchádzajúcich názorov a hovorí o „pripomienke, kde symbol a spomienka majú dvojakú rolu, hoci do nich nevstupuje ani reaktualizácia, ani snaha zreprodukovat historickú udalost'. Ide predovšetkým o vôlu znovu ukázat’ príklad daný Ježišom, ako aj okolnosti, v ktorých vyslovil svoje prikázanie.“ (BERGER 1976: 75) V tomto zmysle jej slová o hlavnom cieli rituálu, ktorým má byt jeho teologický účinok, potvrdzuje už citovaný Éric Palazzo. K diskusii je však treba pripomenút, že táto teatrológmi dosial nevel'mi študovaná téma má obrovské množstvo konkrétnych podôb prevedenia rituálu, z ktorých len málo má zhodný priebeh. ${ }^{12}$ Ak má Mandatum podobný scenár, tak je to viac v diecéznych, teda sekulárnych komunitách, kde sa odohráva na formálnejšej úrovni. V kláštoroch sa často zakladá na vlastnostiach danej komunity a do vel'kej miery na ňu vplýva privátny charakter kláštorného spoločenstva.

Tak je to aj v prípade českej verzie, pochádzajúcej z Kláštora sv. Jiří na pražských Hradčanoch, ktorej dramatický potenciál spočíva $\mathrm{v}$ prepojení viacerých tém a tým dosiahnutej mnohoznačnosti a mnohovrstevnatosti tohto rituálu. Hned' treba pripomenút, že ide o ženský benediktínsky kláštor, kde sa drvivá väčšina obradov (okrem omší) odohrávala v čisto ženskom kolektíve. Ked’že išlo o inštitúciu založenú Přemyslovcami a staršiu ako biskupstvo samo, jej spoločenská dôležitost̉ sa prejavovala aj tým, že príslušníčky tejto náboženskej komunity boli väčšinou mladé dámy z dvorských kruhov, abatiša bola príbuzensky napojená na královský rod.

11 Dva týždne pred Vel'kou Nocou. Mení sa charakter liturgie, vynechávajú sa niektoré spevy, zahal’ujú sa zobrazenia kríža, Krista, svätcov s cielom viac sa ponorit do fundamentu Kristovho utrpenia.

12 Napriek tomu sú v jednotlivých repertoároch spevy, ktoré sa vyskytujú systematicky. Iné však len ojedinele, resp. výnimočne. 


\section{Svatojiřské Mandatum}

Mandatum u Sv. Jiří nachádzame iba v liturgii Zeleného štvrtka (čoho príčinou môže byt nedostatok zachovaných prameňov), a to konkrétne v desiatich rukopisoch obsahujúcich hudobný zápis, jedenásty a zároveň najstarší spisuje len texty jednotlivých spevov. Z notovaných rukopisov ide predovšetkým o procesionály - teda knihy malého prenosného formátu, čo značí, že boli určené na používanie v praxi. ${ }^{13} \mathrm{~V}$ ôsmich z nich sa objavuje úplne identický repertoár, všetky sú datované z prelomu 13. a 14. storočia. ${ }^{14}$ $\mathrm{Z}$ týchto ôsmich procesionálov, napriek tomu, že ide o hudobné rukopisy, v siedmich nachádzame pomerne dlhý oddelený text - úplne identické ordo, teda smernice k tomu, ako tento obrad vykonávat. ${ }^{15}$ Umiestnenie textu v hudobnom repertoári sa mierne líši, je bud' na jeho začiatku alebo uprostred, pred klúčovou antifónou Mandatum novum. Text síce indikuje kto čo spieva, no predovšetkým určuje súbor úkonov, ktoré sa k rituálu viažu. Okrem ordo, ktoré je zaznamenané v procesionáloch, sú smernice k priebehu slávnosti konformne, no ešte o niečo detailnejšie opísané v d’alšom rukopise, v knihe liturgických smerníc, tzv. Liber ordinarius. ${ }^{16} \mathrm{~V}$ tomto kódexe sa hovorí aj o Mandatum pauperum, ktoré je súčastou dopoludňajších liturgických úkonov, zápis sa však obmedzuje na súpis spevov, ktoré umývanie nôh a rozdávanie almužny sprevádzajú.

\section{Repertoár a "scenár"}

Vd’aka obom opisným textom sa dozvedáme, že Mandatum sororum sa odohrávalo po večernej modlitbe vešpier. $\mathrm{V}$ d’alšom texte predkladám pomerne podrobný opis jeho priebehu a úplný repertoár pre lepšie oboznámenie čitatela s pomerne neznámou problematikou.

Obrad začína zostupom abatiše z jej komnaty v sprievode slúžok a komornej, ostatné sestry ju čakajú sediac v kapitule. ${ }^{17}$ Sled gest sprevádzajúcich prvý spev je vel'mi dôsledne viazaný na jeho text. Predspeváčka zaintonuje antifónu Ante diem festum.

Ante diem festum pasche sciens Ihesus quia eius hora venit ut transeat ex hoc mundo ad patrem. Et cena facta surrexit linteo praecinxit se, misit aquam in pelvem, cœepit lavare pedes discipulorum, venit ad Petrum dicit ei Simon: non lavabis mihi pedes in aeternum.

Respondit Jesus: si non lavero tibi non habebis partem mecum.

Domine non solum pedes tantum sed manus et caput.

13 V niekol'kých procesionáloch nájdeme o pár fólií neskôr zápis velkkonočnej liturgickej slávnosti.

14 Ide o plodné obdobie kláštora pod vedením abatiše Kunhuty počas aktivity svatojiřského skriptória.

15 V prípade vel'konočných slávností ide o vel’mi strohé rubriky zapísané medzi jednotlivými spevmi. V tomto prípade je text koncentrovaný do jedného korpusu v rozmedzí niekol'kých fólií.

16 Tento rukopis pochádza z rovnakého obdobia ako procesionály. Je to kniha liturgických smerníc pre úkony a repertoár v priebehu celého liturgického roka, má čisto textový charakter.

17 Kapitulná sála je pre komunitu významovo niečo ako rodinný stôl, miesto stretávania sa, kde sa začína každý spoločný obrad (teda miesto, kde sa všetci zídu) a zároveň miesto, kde sa v prípade potreby hovorí o vnútorných problémoch komunity, ide o intímny priestor komunity. 
Pri večeri Ježiš vstal od večere, odložil si vrchný odev, vzal si zásteru a opásal sa. Potom nalial do umývadla vodu a začal umývat učeníkom nohy. Tak prišiel k Šimonovi Petrovi, ten mu povedal: „Nikdy mi nebudeš umývat nohy!“

Ježiš mu odpovedal: „Ak ta neumyjem, nebudeš mat' so mnou podiel.“

„Pane, teda nielen nohy, ale aj ruky a hlavu!"18

Ked' predspeváčka (cantrix) spieva slová „cena facta“, abatiša vstúpi do kapituly, ukloní sa pred stĺpom a pri slovách „ccepit lavare“ sa pripraví na akt umývania nôh. So slovami spevu „venit ad Petrum“ začne umývat sestrám nohy. Na prvý pohlad ide o pomerne jednoduchý scenár. Aká je ale funkcia stĺpa, ktorý má stát približne uprostred kapituly a čo je dôvodom, že sa pred ním abatiša ukloní na prejav úcty?19

Inou otázkou, ktorá takisto pozýva k reflexii, je dôvod rozdelenia tohto jednoliateho spevu na tri časti pomocou iniciál, vo všetkých rukopisoch zhodne (v mnou prepísanom texte novú iniciálu reprezentuje podčiarknuté hrubé písmeno). Ak hladáme spev v prameňoch z iných európskych miest (a že sú hojné), všade zhodne nachádzame jedinú a nerozdelenú antifónu a tak ju uvádzajú aj editované databázy. Čo však viedlo pisárov svatojiřského skriptória, aby práve po prvej scéne, v dialogickej časti, tento spev vizuálne rozdelili, ked' ordo sa o tom nezmieňuje? Tu vzniká priestor pre polemiky o eventuálnej snahe podčiarknut dialogický charakter spievaného kusu. Obdobná situácia nastáva hned' v nasledujúcej antifóne:

Domine tu michi lavas pedes ? Respondit Ihesus et dixit ei : Si non lavero tibi pedes, non habebis parte mecum.

Domine non tantum pedes sed et manus et caput.

„Pane, ty mi chceš umývat̉ nohy?“ Ježiš mu odpovedá a hovorí: „Ak taa neumyjem, nebudeš mat’ so mnou podiel."

„Pane, teda nielen nohy, ale aj ruky a hlavu!“

Táto je ale o to zarážajúcejšia, že znovu cituje už raz vyslovený text. Ordo sa k nemu nevyjadruje. Zdvojenie Petrovho odmietnutia môže mat význam teologický. ${ }^{20}$ A možno je to len snaha vyzdvihnút dialogickú formu dvoch melodicky odlišných, no pritom textovo vel'mi príbuzných spevov. Slávnost̉ dalej pokračuje antifónou:

18 Preklady jednotlivých spevov sú zhotovené kompiláciou biblických veršov v prípade, že antifóna text cituje (s vol'bou katolíckeho prekladu, ktorý je priamym prekladom citovaného Hieronymovho textu pôvodných antifón) a vlastných autorkiných prekladov.

19 O presnej architektonickej podobe svatojiřského kláštora existujú zatial' len dohady. Detaily, akým je napríklad dosial' nikým neštudovaný a nezmieňovaný stíp uprostred kapituly nekorešpondujú so súčasnou fázou archeologického výskumu či so snahami o topografickú rekonštrukciu stredovekej podoby hradného areálu.

20 Ide o zdôraznenie slov „mat so mnou podiel“, ktoré dokazujú príslub večného královstva, a takisto z hladiska dejín judaizmu symbolizujú príslub Boha svojmu ludu Izraela. 
Postquam surrexit dominus a cena, misit aquam in pelvem, coepit lavare pedes discipulorum.

Hoc exemplum reliquit eis.

Pán vstal od večere, nalial do umývadla vodu a začal umývat učeníkom nohy, takto im zanechal príklad.

Počas nej mladé sestry začnú pred kazatel'ňou okiadzat' kadidlom. To, kto stojí na kazatelni (pravdepodobne predspeváčka), nie je jasne stanovené. Zaujímavé však je, že text znova sumarizuje už spievaný evanjeliový úryvok, k tomuto sa pripája aj krátky komentár (už bez akéhokolvek vizuálneho oddelenia, je to tak aj v editovaných verziách). Po tomto speve nasledujú tri d’alšie antifóny nadväzujúce práve na onen komentár:

Si ego dominus et magister vester lavi vobis pedes quanto magis vos debetis alter alterius lavare pedes. Exemplum enim dedi vobis ut quemadmodum ego feci vobis ita et vos faciatis.

Vos vocatis me magister et domine bene dicitis sum etenim. Si ego lavi vestros pedes dominus et magister et vos debetis alter alterius lavare pedes.

Cena facta dixit Jesus discipulis suis amen amen dico vobis unus vestrum est hic qui me traditurus est in hac nocte.

„Ked’ som vám teda ja, Pán a Učitel', umyl nohy, aj vy si máte navzájom umývat nohy. Dal som vám príklad, aby ste aj vy robili tak, ako som urobil ja vám.“

„Vy ma nazývate Učitel' a Pán, a dobre hovoríte, lebo to som. Ked’ som vám teda ja, Pán a Učitel’ umyl nohy, aj vy si máte navzájom umývat nohy.“

Ked’ skončila večera, Ježiš povedal svojim učeníkom: „Amen, hovorím vám, že jeden z vás ma zradí.“

Ak sa pozrieme na štruktúru doterajšieho diania, smeruje od uvedenia scény, akcentuje dialóg medzi Petrom a Kristom a zdôrazňuje dôvod daného gesta. Neostáva ale len pri geste samotnom, ktoré by dospievaním antifón malo byt zavŕšené. Príbeh sa dynamicky rozvíja v zmysle biblických udalostí, spieva sa d’alší spev, po formálnej stránke sa jedná o hymnus. Dalo by sa hovorit’ o strofickom žalospeve s refrénom: 
Ymno dicto exierunt

in montem oliveti

orabant omnes dicentes:

Domine adjuva nos.

O, Iuda.

Ad Christum turba plura venit

iudeorum agmina

pacem iudas proferebat

tradendo Dominum.

O, Iuda.

Cum ad locum obtineret

tunc inter duodecim

fraude facta pro argento

vendidisti Dominum.

O, Iuda.

Bonum tibi profuisset

nec nasci in saeculo

quam per osculum iniquum

vendidisti Dominum.

O, Iuda.
Ked’ dospievali hymnus, vyšli

na Olivovú Horu.

V̌̌etci sa modlili hovoriac:

Pane, pomôž nám!

Ó, Judáš!

Ku Kristovi pristúpil hojný

privedený zástup židov.

Judáš prejavil/ ponúkol pokoj

a tým zradil Pána.

Ó, Judášs!

Ako prichádzal na miesto

$v$ zástupe svojich dvanástich,

tak si spáchavši podvod kvôli

peniazom zapredal Pána.

Ó, Judáš!

Bolo by sa ti dobre stalo,

keby si sa vôbec nenarodil,

než aby si hanebným bozkom

zapredal Pána.

Ó, Judáš!

Ešte pred začatím žalospevu abatiša odíde z kapituly a zdrží sa mimo nej. Spev sumarizuje zajatie Krista v Olivovej záhrade, ale len okrajovo. Jeho hlavnou témou je Judášova vina a lamentácia nad ním. Prítomný refrén (na stredoveký hymnus vel'mi neobvyklé) zvyšuje lamentatívny charakter spevu. Treba tiež pripomenút, že v jednom z evanjelií reaguje Judáš na to, že Mária Magdaléna umýva nohy Kristovi stažnostou, že peniaze vyhodené za vzácny olej, ktorým mu potom nohy pomazala, sa radšej mohli rozdat̉ chudobným (Ján 12, 4-7). Ide o spev, ktorý sa okrem Sv. Jiř́i a dvoch rukopisov z Klosterneuburgu nikde neobjavuje, napriek už niekol'ko desaţročí trvajúcemu skúmaniu. Jeho posledná strofa parafrázuje iný spev, ktorý je súčastou ofícia na Vel'ký piatok.

Obrad pokračuje spevom d’alšej antifóny:

Simon dormis? Non potuisti una hora vigilare mecum?

Vel Iudam non vides? quomodo non dormis sed festinat tradere me iudeis.

Šimon, spíš? Ani len jednu hodinu si nevládal bdiet??

Judáša si nevidel? Nespi viac, Judáš sa náhli ma zradit'.

Prvá čast’ predstavuje vetu z evanjelia, zatial'čo druhá čast’ je dokomponovaná a takisto ostáva špecifickou pre východnú čast̉ územia západnej liturgie (má o niečo málo viac konkordancií než Ymno dicto). Týmto sa uzatvára biblická scéna poslednej večere 
a jej dodatkov. Eva Stehlíková píše, že „mnoho liturgických dramat postrádá logickou strukturu, kauzální řazení epizod a propracování postav“" (STEHLÍKOVÁ 1998: 63). V tomto dramaticky potenciálnom tvare je to presne naopak. Čo sa týka konzekventnosti usporiadania scén, dalo by sa hovorit o perfekcii umocnenej kontextualizáciou rítu v rámci liturgie celého Velkého týždňa.

\section{Kult Márie Magdalény}

Obrad sa dostáva k d’alšej téme, tá súvisí s postavou Márie Magdalény. Abatiša sa vráti do kapituly, postaví sa k už spomínanému stípu, jej návrat dopíňa vôňa kadidla zo znovu používanej kadidelnice. Začne sa spievat̉ responzórium ${ }^{21}$ Accessit ad pedes, pri ktorom sa abatiša skláňa a všetky sestry okolo nej si tiež poklaknú, ostanú tak až do spevu verša:

Accessit ad pedes Jesu peccatrix mulier Maria et osculata est, et lavit lacrimis, et tersit capillis, et unxit unguento.

Verset: Dimissa sunt ei peccata multa quoniam dilexit multum.

K Ježišovým nohám pristúpila hriešna žena Mária, začala mu ich bozkávat, máčat slzami, utierał svojimi vlasmi a natrela ich voňavým olejom.

Verš: Odpúšłajú sa jej mnohé hriechy, lebo velmi milovala.

Špeciálne pietne gesto sprevádzajúce responzórium v kláštore na Pražskom hrade prezrádza mnoho o úcte Márie Magdalény. Pre ženskú komunitu to v danej dobe v celoeurópskom kontexte nie je nič neobvyklé. Kult svätice možno u Sv. Jiří pozorovat $\mathrm{z}$ mnohých prejavov. ${ }^{22} \mathrm{~V}$ tomto mieste nadväzuje bezprostredne na príbeh o vine: síce Judášovej zrady, ale takisto hovorí o „hriešnej žene“ akoby vina mala splynút v jednu a oná žena ju zmyla svojou snahou a gestom pokory. Práve na spev verša, ktorý je textovou konklúziou zmytia viny prostredníctvom gesta umytia Kristových nôh, sa všetci postavia. Symbolicky tak tento akt pokory akceptujú a prisvoja si ho. Abatiša, ktorá chýbala v spoločenstve sestier, ked’ sa spieval žalospev o Judášovi, sa vracia práve na spev o Máriinom očistení, stojí uklonená v strede, je tou, ktorá už podla Kristovho príkladu všetkým umyla nohy. Reprezentuje postavu Magdalény alebo sa ukláňa pred stĺpom, ktorý plní túto úlohu? Po speve nasleduje antifóna, ktorá dala názov celému rituálu:

21 Responzórium je formálne rozvinutejší druh spevu, je dlhší, ornamentálnejší, má svoj verš a v obvyklom používaní sa viaže na predchádzajúce čítanie. V tomto repertoári však čítanie nie je (len vo forme pamäti) a je to zároveň jediné responzórium v obrade Mandata. Zvyčajné repertoárové zaradenie tohto spevu je na sviatok Márie Magdalény.

22 Sviatky Márie Magdalény sú v kalendároch rukopisov vpísané červenou, čím sa jej sviatok zarad'uje medzi dôležitejšie v kláštore. Samotný repertoár jej sviatku je rozvinutý a prepracovaný. V Pasionáli abatiše Kunhuty sa nachádza planctus Márie Magdalény (pričom obvyklá forma planctu nad smrtou Krista bola predovšetkým žalospev Márie, jeho matky). Dosvedčujú ho aj viaceré zobrazenia Márie Magdalény v Pasionáli, ako si vysvetlíme neskôr. Vel'konočná slávnost̉ z kláštora obsahuje tri scény, pričom magdalská je zjavne uprednostnená jednak rozsahom a tiež umiestnením pred učenícku scénu. 
Mandatum novum do vobis ut diligatis invicem sicut dilexi vos, dicit Dominus.

„Nové prikázanie vám dávam, aby ste sa navzájom milovali, ako som ja miloval vás, " hovorí Pán.

Týmto sa zdanlivo uzatvára hlavná myšlienka obradu a zdalo by sa, že všetko potrebné už bolo vykonané i vyjadrené. Mandatum však pokračuje, pretkávajú sa v ňom dve ostávajúce témy - teda Mária Magdaléna a caritas.

In hoc cognoscent omnes quia mei estis discipuli,

si dilectionem habueritis ad invicem.

Podla toho všetci spoznajú, že ste moji učeníci,

ak budete mat lásku jeden $\mathrm{k}$ druhému.

Po speve podobného charakteru ako antifóna Mandatum novum sa repertoár opät vracia k téme Márie Magdalény, tentokrát vel'mi svojským spôsobom. Repertoár predostiera dve melodicky príbuzné antifóny s kvázi refrénom so slovami „svätá Mária“:

Lavatrix Dominicorum pedum

lava nostrorum maculas criminum, sancta Maria.

Dimissa sunt tibi peccata multa quoniam dilexi multum tuo interventu eodem amore dilectionis ita habundemus ut mereamur misericordie mundari fonte sancta Maria.
Umývatel'ka nôh Pána

zmy poškurny našich previneni, svätá Mária!

Boli ti odpustené mnohé hriechy, pretože si mnoho milovala.

Na tvoj zásah a tou istou láskou nech sme hodni

byt' očisteni prameňom milosrdenstva, suätá Mária!

Ide o istý druh modlitby, kedy sa konvent obracia priamou rečou s konkrétnou prosbou očistenia k svojej patrónke, čo logicky dopĺn̆a predchádzajúci pietny akt. Na spevoch je zvláštnostou, že okrem pražského Mandata sa inde nevyskytujú. Možno predpokladat, že antifóny boli skomponované lokálne za účelom doplnenia tohto obradu. Zodpovedali by tomu aj mierne melodické nedokonalosti a spôsob notového zápisu, ktorý aplikuje na oba spevy rovnaké princípy a teda možno usúdit, že bolo ciel’om ich považovat za jeden spev. Ak ich vnímame ako celok, ide o spev s refrénom, akoby so snahou zaistit rovnováhu vnútorného napätia obradu. Akoby mal spev vytvorit’ niečo ako protipól k hymnu - žalospevu s výčitkou Ymno dicto, zatial’čo tu ide o slávny spev a modlitbu zároveň.

Nasledujúca antifóna potvrdzuje Máriino gesto a pripomína, prečo zhromaždenie oroduje u Márie Magdalény, zároveň sa po tretí raz hovorí o odpustení jej hriechov: 
Maria ergo unxit pedes Jesu et extersit capillis suis et domus impleta est ex odore unguenti.

Dimissa sunt ei peccata multa quoniam dilexit multum.

Mária pomazala Ježišovi nohy a poutierala mu ich svojimi vlasmi. A dom sa naplnil vôňou pomazania.

Odpúštajú sa jej mnohé hriechy, lebo velmi milovala.

Až d’alší spev je zmienený v smerniciach ordo. Pri jeho príležitosti sa abatiša znova vráti do kapituly, aby tentokrát umyla ruky všetkým zúčastneným. A tak obrad pokračuje novým úkonom, počas neho sa spievajú spevy na tému vzájomnej lásky.

Diligamus nos invicem quia caritas ex Deo est et qui diligit fratrem suum ex Deo natus est et videt Deum.

Milujme sa navzájom, lebo láska je z Boha a ten, kto miluje brata, je z Boha zrodený a Boha videl.

Ubi est caritas et dilectio ibi sanctorum est congregatio.

Ibi nec ira est nec indignatio sed firma caritas in perpetuum.

Christus descendit mundum redimere ut liberaret a morte hominum.

Exemplum praebuit suis discipulis ut sibi invicem pedes lavarent.

Kde je dobrota a láska, tam je spoločenstvo svätých.

Tam niet ani hnevu, ani neprávosti, ale je tam pevná dobrota na večnost'.

Kristus prišiel na svet, aby ho uzdravil a človeka oslobodil od smrti.

Svojim učeníkom dal príklad, aby si jeden druhému umývali nohy.

Maneant in nobis spes, fides, caritas tria, haec major autem his est caritas.

Ostávajú v nás nádej, viera, láska, no najväčšia z nich je láska.

Pri poslednom citovanom speve vyjde priorka, ${ }^{23}$ aby umyla abatiši nohy. Tá po tom, čo všetkým umyla ruky, sedí mimo kapituly pred kňažiskom spolu s lektorkou a troma d’alšími sestrami. K nej podstúpi priorka, umyje jej nohy. Medzitým znie spev:

Stans retro Maria secus pedes Domini Jesu lacrimis coepit rigare pedes ejus et capillis capitis sui tergebat osculabatur pedes ejus et unguenti ungebat.

Mária, stojac v úzadí, vrhla sa k nohám pána Ježiša, slzami mu ich umývala, vlasmi osúšala, bozkávala mu ich a pomazala ich olejom.

23 Priorka bola kvázi zástupkyňa abatiše, hierarchicky druhá najdôležitejšia v kláštore. 
Je zaujímavé, že tento spev sprevádza akt umývania nôh - naviac v úzadí mimo ostatné zhromaždenie, ako to evokuje začiatok spevu - a to najvyššie postavenej osoby v kláštore. Opät sa vynára hypotéza, či abatiša neplní reprezentatívnu funkciu postavy Márie Magdalény. Abatiša sa potom vracia do kapituly. Je odetá do kožušín, nasledujú ju dve prisluhovatelky a nesú vodu. Zhromaždenie sa jej postaví na pozdrav, priorka jej naleje na ruky vodu. Pripravená lektorka v tej chvíli zaintonuje antifónu:
Congregavit nos Christus ad glorificandum se ipsum,
reple Domine animas nostras sancto spiritu.
Zhromaždil nás Kristus aby sa oslávil,
naplň Pane naše duše svätým duchom.

\section{Prekvapivá konklúzia obradu}

Potom lektorka číta akési verše, no nič bližšie (ani len incipit) sa o nich z orda nedozvedáme. $\mathrm{V}$ repertoári nachádzame len spevy, ktoré sa viac nespomínajú ako spevy. Čo do počtu - teda tri, súhlasili by s počtom čítaných veršov. Ide ale jasne o spevy, pretože je k nim zaznamenaná aj notácia, a naviac tri ostávajúce nasledovné spevy sú vyňaté z iných repertoárov liturgického roku. V repertoári Mandata mimo svatojiřský kláštor nemajú obdobu:

Maria Magdalena et Maria Iacobi et Salome sabbato quidem siluerunt secundum mandatum in lege cum autem transisset sabbatum ementes aromata veniunt ungere Ihesum, alleluia, alleluia.

Mária Magdaléna, Mária Jakubova a Salome, ked' pominula sobota, podla predpisu zákona nakúpili voňavé oleje, aby išli pomazat Ježiša, aleluja, aleluja.

Veni domine visitare nos in pace ut lætemur coram te corde perfecto.

Príd’ nás Pane navštívit v mieri, aby sme sa radovali pred tebou s dokonalým srdcom.

Bethleem non es minima in principibus Juda, ex te enim exiet dux qui regat populum meum Israel, ipse enim salvum faciet populum suum a peccatis eorum.

Betlehem, nijako nie si najmenší spomedzi judejských miest, lebo z teba vyjde vodca, ktorý bude kralovat môjmu ludu Izrael. On zachráni svoj lud od jeho hriechov. 
Prvá antifóna je zjavne vel'konočná, ${ }^{24}$ hovorí o známej scéne, ako tri Márie kráčajú k hrobu, aby pomazali Kristovo telo. Spev anticipuje udalosti a dokonca neváha použit ani radostné zvolanie aleluja, ktoré bolo počas posledných štyridsiatich dní prísne zakázané. ${ }^{25}$ Zdanie, že by mohlo íst’ o antifónu vhodnú $\mathrm{k}$ vel'konočným liturgickým slávnostiam, je legitímne, hoci sa tak stalo až v období posteriórnom zápisu Mandata. ${ }^{26}$ V svatojiřských rukopisoch z neskorého 14. a začiatku 15. storočia sa objavuje trikrát, práve v kontexte vel'konočných slávností, ktoré sú jednoduchšie a strohejšie než ich komplexnejšia podoba tzv. trojstupňových hier, teda hier s tromi scénami (STEHLÍKOVÁ 1998: 16), zaznamenaná v niekolkých zo študovaných procesionálov ${ }^{27}$ a iných rukopisoch z prelomu 13. a 14. storočia. V Pasionáli abatiše Kunhuty scénu ilustruje známa iluminácia troch žien prichádzajúcich $\mathrm{k}$ hrobu, kde ich víta anjel, jednotlivé postavy popisujú rubriky. Prečo sa ale tento spev ocitol v zdanlivo nesúvisiacom repertoári? Prvou zo zmienených žien, zároveň prítomnou vo všetkých verziách nájdenia prázdneho hrobu, je Mária Magdaléna, bývala hriešnica, ktorá pokorným skutkom umytia Kristových nôh zmyla svoje viny. Antifóna anticipuje vel'konočné udalosti, no nepovie podstatné.

Pre účastníčky obradu je zrejmé, že novú „bezhriešnost“" Márie Magdalény potvrdzuje vel'ká milost̉ toho, že sa dozvedela vôbec ako prvá o Kristovom zmŕtvychvstaní. Iná ilustrácia Pasionálu vyobrazuje scénu, ako Mária Magdaléna rozpráva Márii, Kristovej matke o zmŕtvychvstaní, pretože ju k tomu privileguje práve prvenstvo v poznaní vel'konočnej zvesti. Touto antifónou sa kompletizuje trojúrovňové vnímanie postavy Márie Magdalény v svatojiřskom kláštore, ktoré perfektne zapadá do jej celoeurópskeho vnímania v období stredoveku. ${ }^{28}$ Prvá úroveň postavy podla Victora Saxera je obrátená hriešnica. Toto vnímanie vo verzii svatojiřského Mandata ilustrujú spevy rozprávajúce príbeh, ktorý sa udial pri večeri v Šimonovom dome. Druhou úrovňou je kontemplujúca duša, v obrade Mandata zdanlivo absentujúca. Ked' však zoberieme do úvahy pretkávanie spevov o Magdaléninom geste spolu s tými, ktoré rezumujú akt pokory - teda umývanie nôh, je zjavné, že Mária Magdaléna je poslušnou poslucháčkou Kristovho učenia, ktoré prostredníctvom skutkov vedie k perfekcii. Velkonočná antifóna v závere obradu dosvedčuje tretiu úroveň stredovekého vnímania tejto ženskej svätice, a tou je vel'konočná žena.

Vo svetle interpretácie tohto velkonočného spevu možno nasledujúcu antifónu Veni Domine chápat ako nádejeplnú modlitbu, pretože zástupkyňa komunity, abatiša, práve učinila rovnaké gesto pokory a všetky sestry boli obmyté spolu s ňou, a teda majú právo na účast na zmŕtvychvstaní. Zaujímavé je, že spev pôvodne pochádza z adventného repertoáru (prípravné obdobie na narodenie Krista) a jeho výber musel byt velmi cie-

24 Antifóna je nemenný celok, o to viac, ak je vybraná z iného existujúceho repertoáru. V stredoveku nebolo možné spev nijak skracovat’, pretože po formálnej hudobnej stránke by sa rozpadol. Takto má však z teologického aspektu potenciál rozlúštit dôvod jeho translácie z iného repertoáru do repertoáru Mandata.

25 Je pravdou, že charakter Zeleného štvrtku bol v období vrcholného stredoveku v mnohom slávnostnejší a radostnejší ako v neskorších obdobiach, kedy nadobudol prísne pôstny ráz v dôsledku cirkevných koncilov a reforiem.

26 Uvádza ju (LIPPHARDT, vol. IX: 1097; SCHULER 1951: 131).

27 V týchto je ekvivalentom responzória Dum transisset sabbatum.

28 Viac o vnímaní kultu Márie Magdalény a jeho troch úrovní hovorí Saxer (SAXER 1959: 325-350). 
lavedomý. Podobne je to aj pri speve, ktorý repertoár uzatvára. Betlehem non es minima má tiež svoje korene v advente, jeho obsah je však o niečo menej zrozumitel'ný v kontexte práve vykonaného obradu. Evokácia záchrany od hriechov je zrejmá, no prečo Betlehem, ked' v repertoári je mnoho iných spevov o spáse a zbavení sa viny, to ostáva vecou polemiky. Jarmila Veltruská v úvode o postave Márie Magdalény na margo svätice uvádza, že je „často nejdůležitější lidskou postavou, a to nejen v rovině dramatické, ale i symbolické, jako vzor a představitelka celého lidstva, která se obrátila od hříchu ke svatosti." (VELTRUSKÁ 2006: 41) Aj na základe tohto tvrdenia možno vytvorit interpretačný predpoklad, že by ústredným odkazom tejto antifóny bola práve postava Márie Magdalény. Nils Holger Petersen túto domnienku schvaluje,$^{29}$ mohlo by íst́ o figuratívnu interpretáciu postavy Márie Magdalény, ktorá, hoci bola hriešnica, a teda v teologickom ponímaní „minima - najmenšia“, bolo to len zdanlivé, pretože svojím obrátením sa stala vel'kou sväticou, ktorá môže inšpirovat’ a viest’ aj skutky zbožných rehol'níc.

Počas troch posledných spevov sa hojne užíva kadidlo, sestry pietne stoja. Napokon priorka vyjde z kapituly, aby trikrát udrela na tabul'u a dala tak sonórne znamenie lektorke, ktorá povie: „Surgite eamus hinc“ (Vstaňme, pod'me odtialto). ${ }^{30}$ Sformuje sa sprievod: za kadidlom sa pripravia sestry so sviecami, tri iné sestry, ktoré nesú krištálovú nádobu, potom prisluhovatel'ky, a na konci celého zhromaždenia kráča abatiša. Takto sa už v tichosti presunú do refektára, miesta obvyklých spoločných jedál, aby tu zrealizovali symbolickú večeru. Abatiša rozdáva sestrám chlieb, prijímajúc ho jej každá sestra pobozká ruku. Chlieb sa zapíja vínom a medovinou, nápojom špecifickým pre región. Na záver sa abatiša posadí pred celé zhromaždenie, ordo sa opät zmieňuje o tom, že je odetá do kožušín, a všetkým pripije. Počas večere lektorka číta čítanie, ${ }^{31}$ nie je však uvedené aké. Na záver vysloví verš „Adiutorium nostrum in nomine Domini“ (Naša pomoc v mene Pánovom), po ktorom sa zhromaždenie presunie na záverečnú modlitbu dňa do obvyklého chrámového priestoru.

\section{Résumé}

Ak by sme mali bilancovat dohady v úvode citovaných názorov na dramatickost̉ rituálu Mandata, možno by sme prišli k záveru, že aj ked’ ide o zdanlivo extra-liturgický útvar, ked’že sa odohráva mimo zaužívaných modlitieb a jeho súčastou je symbolická komunitná večera, jeho vnútorná kompozícia, úkony a priebeh majú čisto liturgický charakter (PETERSEN 2004: 91). Rituál má predovšetkým symbolický význam, ktorý prehlbuje spoločenskú, resp. spirituálnu angažovanost’ zúčastnených sestier, o to viac, že symbolika je im priblížená prostredníctvom postavy, ku ktorej v kláštore pestovali kult. Preto lepšie, než hovorit’ o dramatických momentoch obsahujúcich náboj teatrality, bude zhrnút dramatické tendencie rituálu.

29 Na základe osobnej korešpondencie autorky štúdie s Petersenom.

30 Je to citát Krista, ktorý vyslovil počas svojej prorockej reči v rámci poslednej večere (Ján 14, 31).

31 V benediktínskej tradícii každé spoločné jedlo (teda obedy a večery) sprevádza čítanie Biblie alebo cirkevných otcov. Deklamuje ho lektorka, ktorá jedáva inokedy, služba sa každý týždeň strieda. 
Podstatné je miesto konania obradu, abatiša umýva spolusestrám nohy v kapitulnej sále, ktorá má význačné miesto pre vnútorný život komunity. Uprostred tohto priestoru sa nachádza stĺp, ktorý funguje v symbolickej rovine. Matka predstavená sa pred ním pri každom vstupe do kapituly ukloní, možno predpokladat, že zvyšok zhromaždenia podobne.

Frapujúcim prvkom je zvýraznenie dialogického charakteru antifóny Ante diem festum, žial', pre nás s istotou pozorovatel'né len vo forme písomného prameňa. Dôraz na tento dialóg kladie tiež repríza jeho poslednej časti v nasledujúcej antifóne. Takisto je zaujímavá dôslednost gest pri týchto spevoch: abatiša vstupuje do kapituly so slovami „cena facta“, pri „,oepit lavare“ sa pripraví a pri „venit ad Petrum“ začne realizovat úkon samotný. Pri speve, ktorý textovo sumarizuje Kristovo umytie nôh učeníkom, Postquam surrexit, sestry začínajú používat kadidlo. Narácia evanjeliovej scény je dôsledne príčinne a časovo poskladaná, napriek tomu, že ide o kompilát viacerých antifón a napokon hymnu. K emotívnemu náboju tejto scény prispieva práve hymnus - žalospev Ymno dicto, jeho opakovaný refrén v speve označuje objekt viny. Koncipuje sa tak budúce premostenie s dalšou artikulovanou témou.

Spôsob performancie responzória Accessit ad pedes možno dešifrovat vo viacerých symbolických rovinách - všetci klačia okolo abatiše uklonenej pri stĺpe uprostred zhromaždenia. Má jej „postava“, zjavne stelesnenie honoru, ktorý zasluhuje úctu, náznakový význam pre personifikáciu Krista či Márie Magdalény? V celej nasledujúcej časti je velmi výrazná postava Márie Magdalény, čo podporuje rozvíjanie jej kultu v kláštore. Dvojantifóna s refrénom tvorí pomyselný vnútorne rytmický protipól k spevu Ymno dicto.

$\mathrm{S}$ témou caritas nastupuje nový úkon - umývanie rúk. Po tom, čo abatiša nové gesto umývania rúk dov́rši, priorka jej umyje nohy a abatiša sa následne do kapituly vracia zahalená kožušinami. Odev sa spomína aj neskôr pri symbolickej večeri. Či je význam tohto odevu interpretačný alebo funkčný, nevedno. Ked’ sa napokon umývajú ruky, všetci pietne stoja a spieva sa antifóna Congregavit nos akcentujúca moment jednoty.

Konklúzia obradu pokračuje v rovine interpretačnej uvedením troch ostatných antifón nakomponovaných do Mandata z iných repertoárov liturgického roku. Rituál sa tak zároveň zaraduje do širšieho kontextu. Po nich nasleduje symbolická večera, ktorej cielom je nielen pripomienka Kristovej poslednej večere (to sa už stalo umývaním nôh), ale jej dôsledky, ktoré kladú dôraz na moment vzájomného spoločenstva.

Rituál je nabitý symbolmi, gestami, objektmi, ktoré spoločne prispievajú k vytvoreniu špeciálnej ambience. Nils Holger Petersen hovorí o intenzívnom zmyslovom vnímaní (v nadäznosti na definície Érica Palazza) tohto obradu, ku ktorému prispieva celková performancia slávnosti, teda vizuálny aspekt (architektonický priestor, odevy, objekty kadidlo, krištálová nádoba), materiálny (voda, vôňa kadidla) a dotykový (chlieb, víno, medovina) (PETERSEN 2015: 3). Toto zloženie vstupuje priamo do vztahu so zmyslami: sluch so spevom, chut s chlebom a vínom, hmat s vodou, čuch s kadidlom, zrak s celkovým usporiadaním a gestami.

Z liturgického hladiska ide o integrálnu čast̉ slávenia Zeleného štvrtka (a teda prenesene aj liturgického roku). Kontextualizácia je základným východiskom pre chápanie performatívnej stránky tohto rituálu. 


\section{Bibliografia}

AMALARIUS, In I. M. Hanssens. 1948. Amalarii episcopi Operia liturgica omnia, vol. II. Città del Vaticano: Bibliotheca apostolica vaticana, 1948.

BERGER, Blandine-Dominique. 1976. Le Drame liturgique de Pâques. Paris: Beauchesne, 1976.

CHAMBERS, Edmund Kerchever. 1966. The Medieval Stage, vol. II. Meniola: Dover Publications, 1966.

HARDISON, O. B. 1965. Christian Rite and Christian Drama in the Middle Ages: essays in the origin and early history of modern drama. Baltimore: The Johns Hopkins Press, 1965.

HAVSTEEN, Sven Rune, Nils Holger PETERSEN a Heinrich W. SCHWAB. 2007. Creations: medieval rituals, the arts, and the concept of creation. Turnhout: Brepols, 2007.

KANTOROWICZ, Ernts H. 1956. The Baptism of the Apostles. Dumbarton Oaks Papers 9 (1956): 10: 20-251.

LECLERCQ, Henri, 1929-1931. Mandatum. Lavement des pieds. In F. Cabrol a H. Leclercq. Dictionnaire d'archéologie chrétienne et de liturgie, vol. X. Paris: Letouzey et Ané. 1929-1931: 1387-1388, 2007.

LIPPHARDT, Walter. 1975-1990. Lateinische Osterfeiern und Osterspiele. Berlin: W. de Gruyter, 1975-1990.

PALAZZO, Éric. 2016. Les cinq sens au Moyen Âge. Paris: Cerf, 2016.

PETERSEN, Nils Holger. 2004. Carolingian Music, Ritual, and Theology. In id et alii. The Appearances of Medieval Rituals: The Play of Construction and Modification. Turnhout: Brepols, 2004: 89-120.

PETERSEN, Nils Holger. 2015. Ritual. Medieval Liturgy and the Senses: The Case of Mandatum. In Hans Henrik Lohfert Jørgersen et alii. The Saturated Sensorium. Aarhus: Aarhus University Press, 2015: 180-205.

RENAUD-CHAMSKA, Isabelle. 2008. Marie-Madeleine en tous ses états. Paris: Cerf, 2008.

SAXER, Victor. 1959. Le Culte de Marie-Madeleine en Occident. Paris: Librarie Clavreuil, 1959.

SCHULER, Ernst August. 1951. Die Musik der Osterfeiern, Osterspiele und Passionen der Mittelalters. Michigan: Bärenreiter-Verlag, 1951.

STEHLÍKOVÁ, Eva. 1998. A co když je to divadlo? [What If This Is Theatre Anyway?]. Praha: Divadelní ústav/KLP, 1998.

VELTRUSKÝ, Jarmila F. 2006. Posvátné a světské [The Sacred and the Profane]. Praha: Divadelní Ústav, 2006.

YOUNG, Karl. 1967. The Drama of the Medieval Church, vol. 1. London: Clarendon Press, 1967. 


\section{Anna Žáková, M.A}

Ústav Hudební vědy

Filozofická fakulta, Univerzita Karlova, Praha

annazak@hotmail.fr

Anna Žáková, M.A. popri doktorskom štúdiu v Ústave Hudební vědy na Karlovej Univerzite, pôsobí ako pedagóg v École du Choeur Grégorien de Paris, tiež vo viacerých benediktínskych kláštoroch a na Festivale starej hudby $\vee$ Rocamadoure. Vo výskume sa zameriava na performatívny charakter niektorých benediktínskych liturgických slávení a rituálov so špeciálnym zretel'om na svatojiřské prostredie. Skúsenost' sa $\vee$ praxi snaží pretlmočit' prostredníctvom koncertných programov so svojím ansámblom Flores Myrtae ako aj s Choeur Grégorien de Paris.

Anna Žáková is a Ph.D. student at the Department of Music, Charles University. She also lectures at the École du Choeur Grégorien de Paris (France), in several Benedictine monasteries, and at the Festival of Old Music in Rocamadoure. In her research, Žáková specializes in performativity of Benedictine liturgical feasts and rituals, with special regard to the basilica of St. George in the Prague Castle. She strives to test her theoretical knowledge in musical praxis with her ensemble Flores Myrtae and Choeur Grégorien de Paris. 